\title{
NF2 expression levels of gastrointestinal stromal tumors: a quantitative real-time PCR study
}

\author{
Antonio Taddei ${ }^{1}$, Francesca Castiglione ${ }^{2}$, Duccio Rossi Degl'Innocenti ${ }^{2}$, \\ Anna Maria Buccoliero², Francesca Garbini², Cinzia Tommasi', \\ Giancarlo Freschi ${ }^{1}$, Paolo Bechi ${ }^{1}$, Luca Messerini ${ }^{1}$, and Gian Luigi Taddei ${ }^{1}$ \\ ${ }^{1}$ Department of Surgical Pathology, and '2Department of Human Pathology and Oncology, University of \\ Florence, School of Medicine, Florence, Italy
}

\section{ABSTRACT}

Gastrointestinal stromal tumors are the most common mesenchymal tumors of the gastrointestinal tract. Until today, there have been few markers specific for the tumor. This has complicated the differential diagnosis of the neoplasm from tumors of smooth muscle origin. Recently, the proto-oncogene c-kit has been shown to be a very relevant marker as it almost invariably is expressed in gastrointestinal stromal tumors. Radiation exposure, hormonal and genetic factors, particularly neurofibromatosis 2, have been implicated in their development and growth. GIST initiation, either in NF2-associated or in sporadic cases, is linked to inactivation of members of the proteins 4.1 superfamily. The majority of the mutations identified in the NF2 gene result in a truncated protein and are clinically associated with a severe phenotype. Occasionally, missense mutations associated with a mild phenotype may occur. We compared NF2 gene expression in 5 cases with gastrointestinal stromal tumors by quantitative real-time polymerase chain reaction analysis. NF2 gene mRNA expression was assessed in fresh tissue of stomach from 5 consecutive patients. We detected no alterations in NF2 gene expression in the quantitative analyses of the 5 tumors.

\section{Introduction}

Gastrointestinal stromal tumors (GIST) are the most common mesenchymal tumors of the digestive tract. The constitutive activation of the c-kit proto-oncogene is a characteristic genetic alteration in GIST, but alterations in chromosomes 14 and 22 may also play a role in the molecular pathogenesis. Radiation exposure, hormonal and genetic factors, particularly neurofibromatosis 2 (NF2), have been implicated in their development and growth. GIST initiation, either in NF2-associated or in sporadic cases, is linked to inactivation of members of the protein 4.1 superfamily, the merlin/schwannomin, an NF2 gene product. Precisely, about $10 \%$ of sporadic GIST are caused by loss of heterozygosity (LOH) on chromosome $22 \mathrm{q} 12$ of the NF2 tumor suppressor gene, whereas no causative gene is known for the remaining $40 \%^{1-8}$.

Within the 4.1 superfamily, merlin shares the highest degree of homology with a subgroup of proteins including ezrin, radixin, and moesin (ERM proteins), linking the actin cytoskeleton (by an actin-binding region in the C-terminus) to the cell membrane glycoproteins such as the CD44 glycoprotein (by its $\mathrm{N}$-terminal residues) in polarized cells. The N- and C- terminal halves of ERM proteins mutually interact intramolecularly to suppress their binding activities. The C-terminal threonine phosphorylation maintains ERM proteins in the active state by suppressing the intramolecular interaction ${ }^{5,7,9,10}$.

The region of merlin with the greatest structural similarity to the ERM proteins correspond to two-thirds of its $\mathrm{N}$-terminal. The $\mathrm{C}$-terminus of merlin is unique and lacks the conventional actin-binding region of the ERM proteins but it interacts with Factin through the $\mathrm{N}$-terminus $\mathrm{s}^{5,9,11-14}$.

The similarity of merlin to the ERM proteins indicates that its function might be re-

Key words: gastrointestinal stromal tumors, neurofibromatosis 2, quantitative real time polymerase chain reaction.

Correspondence to: Antonio Taddei, MD, Department of Surgical Pathology, University of Florence, School of Medicine, Viale GB Morgagni 85, 50134 Florence, Italy. Tel +39-055-4478121; fax +39-055-4379868; e-mail a.taddeus@tin.it 
lated to those of the ERM proteins: organization of membrane extensions and cell adhesion, membrane traffic and cell signaling ${ }^{15}$. Indeed, merlin interacts, either directly or indirectly, with components of cadherin-mediated cell junctions and with a number of proteins that may influence cell growth regulation including paxillin, erbB2, p21-activate kinase, and p535,7,9,10,13 through MDM2 degradation ${ }^{16}$.

Several experimental studies have demonstrated that merlin overexpression results in a significant decrease in cell proliferation, reversion of Ras-induced transformation, and reduced tumor formation in nude mice. In contrast, inactivation of the NF2 gene leads to the development of cancer through loss of contact-dependent inhibition of growth ${ }^{13,14,17-20}$.

Most of the mutations identified in the NF2 gene result in a truncated protein and are clinically associated with a severe phenotype. Occasionally, missense mutations associated with a mild phenotype may occur.

In this report, we compare NF2 gene expression in 5 cases of GIST by quantitative reverse-transcriptase polymerase chain reaction (RT-PCR) analysis. NF2 gene mRNA expression was assessed in fresh tissue of stomach from 5 consecutive patients. RNA amplification was assessed by RT-PCR and measured quantitatively. Our purpose was to further investigate the possible role of merlin in GIST tumorigenesis and progression.

\section{Methods and results}

Tissue specimens were obtained from 5 consecutive patients affected by GIST surgically treated at the Department of Surgical Pathology (Careggi Hospital, Florence, Italy) during the period August 2005 to July 2006, in which fresh tumor tissue was available for RT-PCR analysis. Two samples were from men and 3 from women. The average age at the time of the surgery was 54 years.

From each fresh surgical specimen, we selected a fragment macroscopically representative of the lesion. Successively, we cut it in half: from 1 half several $5-\mu m$ frozen sections stained with hematoxylin-eosin were obtained to verify the adequacy of the specimens selected for RT-PCR (presence of pathological tissue only); the other half was immersed in RNAlater ${ }^{\mathrm{TM}}$ (QIAGEN, Hilden, Germany), so kept overnight at $+4^{\circ} \mathrm{C}$, and finally stored at $-80{ }^{\circ} \mathrm{C}$ until analyzed.

The thawed specimens were cut in small pieces and homogenized. After proteinase $\mathrm{K}$ digestion $(250 \mu \mathrm{g} / \mathrm{ml}$ for $1 \mathrm{~h}$ at $37^{\circ} \mathrm{C}$ ), total RNA was isolated with 6100 Nucleic Acid PrepStation (manufacturer's protocol). Total RNA (500 ng) was subject to reverse transcription to cDNA using the High Capacity cDNA Archive Kit (Applied Biosystems, Foster City, CA) (manufacturer's protocol). We extracted RNA from all samples, and the RNA concentration and purity in preparations was quantitated spectrophotometrically by measuring their absorbance at $260 \mathrm{~nm}$ and $280 \mathrm{~nm}$. The RNA fragmentation state was estimated with ethidium bromide-stained $1 \%$ agarose gel.

Real-time quantitative PCR was performed on an ABI PRISM 7000 Sequence Detector System (Applied Biosystems). PCR products for NF2 were detected using genespecific primers and probes labeled with reporter day FAM (Assay on Demand, Applied Biosystems). GAPDH was used as endogenous control gene for normalization.

PCR reactions were carried out in 96-well plates with $20 \mu$ per well using 1x TaqMan Universal PCR MasterMix. After an incubation for $2 \mathrm{~min}$ at $50^{\circ} \mathrm{C}$ and $10 \mathrm{~min}$ at $95^{\circ} \mathrm{C}$, the reaction continued for 50 cycles at $95^{\circ} \mathrm{C}$ for 15 sec and $60{ }^{\circ} \mathrm{C}$ for $1 \mathrm{~min}$. The $2^{-\Delta \Delta \mathrm{Ct}}$ method described by Livak et al. ${ }^{21}$ was used to calculate fold expression levels relative to the average value of all the RNA specimens. For each sample of GIST, a specimen of normal mucosa from the same patient was used as control sample.

NF2 expression in all GIST was compared to the average value of expression (reference value) of all the benign tissue. The mean of NF2 relative expression of all GIST showed an expression higher (4.9\%) than the average of all tissue used as calibrator $(P=0.05)$.

The shift of expression level of NF2 as estimated through relative RT-PCR was calculated according to the Wilcoxon Mann Data analysis was performed using the SPSS Version 15 (Chicago, IL) statistical package. A $P$ value $\leq 0.05$ was considered to be statistically significant.

After drawing of the small samples for RT-PCR, the remaining tissues were routinely fixed in $10 \%$ buffered formalin and embedded in paraffin. Five- $\mu$ m-thick sections were stained with hematoxylin-eosin for the morphological evaluation. A c-kit analysis was performed, and all cases resulted positive. Diagnostic criteria used were whose indicated by the most recently revised World Health Organization (WHO) Classification of gastrointestinal stromal tumors.

\section{Discussion}

GIST are the most common mesenchymal tumors of the gastrointestinal tract ${ }^{22}$. The few markers specific for GIST has complicated the differential diagnosis of the neoplasm from tumors of smooth muscle origin. The proto-oncogene c-kit has been recently shown to be a very relevant marker, as it is almost invariably expressed in GIST ${ }^{23-25}$. Mutations of the gene are frequently detected in human GIST, and transfection of the mutant c-kit into murine lymphoid cells has been shown to induce malignant transformation. This is evidence that the mutation of c-kit may contribute to the tumourigenesis of GIST $^{24,26}$. However, as only about half of GIST show c-kit mutations ${ }^{27-29}$, alternative mechanisms leading to malignant transformation of GIST are possible. 
Molecular studies have shown that several different genetic changes occur in GIST. The most frequent alterations in comparative genomic hybridization (CGH) and $\mathrm{LOH}$ studies have been revealed to be losses of chromosomes $22 \mathrm{q}$ and $14 \mathrm{q}$, both in benign and malignant tumors ${ }^{30-32}$. In line with the CGH results indicating losses of 22q, both in tumors with high mitotic activity as well as in tumors with low mitotic activity, which is an indicator of potential malignancy of these tumors. Interestingly, LOH was significantly more frequently detected in tumors with high mitotic activity. Thus, allelic loss at these chromosome sites may be a common and primary abnormality responsible for the development of GIST.

We detected no alterations of NF2 gene expression in the quantitative analyses comprising 5 GIST. However, NF2 gene mutations were identified in 2 GIST cases in a study by Fukasawa et al. ${ }^{33}$, suggesting that NF2 may act as a tumor suppressor in a subset of these tumors. The NF2 gene mutations detected occurred independently of c-kit mutations, since no correlation between NF2 mutations or $\mathrm{LOH}$ at $22 \mathrm{q}$ and the c-kit mutations was observed.

Among the aberrant chromosomal regions, the losses of $9 p$ are of particular interest. Homozygous deletions were found in 2 GIST cases in the restricted area of $9 p$ containing the CDKN2A gene ${ }^{34}$. Since homozygous deletion is one of the known mechanisms for inactivation of a tumor suppressor gene, it may be possible that inactivation of CDKN2A plays a role in tumorigenesis of GIST, at least in some cases. In a recent study, chromosomal changes in GIST were investigated in relation to malignant behavior and the presence of c-kit mutations $\mathrm{s}^{35}$.

Interestingly, associations with malignancy, c-kit mutations and loss of chromosome 9 have been detected. However, only c-kit mutations have been shown to clearly correlate with malignancy and a poor prognosis and thus have been proposed to have an important role as a prognostic factor ${ }^{36}$.

Several factors contribute to genomic instability, and cells accumulate many different genetic changes during carcinogenesis. The multiple forms of genetic changes may reflect cellular heterogeneity seen within individual tumors and heterogeneity between tumors of the same type. This heterogeneity is reflected as differences in the histological, karyotypic, molecular, physiological and biochemical factors that can be observed by examining different parts of the same tumor. In lung cancers, it has been hypothesized that the heterogeneity of bronchial tumors may be a consequence of chronic exposure to numerous different carcinogens, e.g., carcinogens present in tobacco, which leads to several cell clones carrying different genetic changes ${ }^{37}$. This may be the case with other tumors also associated with environmental carcinogen exposure.

Interestingly, many of the genetic alterations detected in invasive lung tumors have been demonstrated also in the bronchial epithelium of both current and former smokers without cancer, indicating that molecular damage is already present in carcinogen-exposed bronchial cells ${ }^{38-40}$. These observations may provide new methods for the early detection of lung cancer. In addition, identification of genetic alterations crucial for the development of lung cancer can be used for cancer prevention and for the development of novel therapies specifically targeted to the disrupted cellular activity ${ }^{37}$. Recent studies have also highlighted the possibility to use genetic alterations as early markers since these are detectable in plasma or serum DNA from cancer patients, including lung cancer patients ${ }^{37,41-45}$.

Understanding the interplay between exposure to specific environmental carcinogens and genetic variability of important genes will be important for the ultimate goal of comprehending cancer etiology. This new knowledge will help in the identification of individuals who are at increased risk of developing cancer and will hopefully lead to better biomarkers for the early detection of cancer and cancer prevention. Frequent LOH detected at $22 \mathrm{q}$ in GIST, especially in malignant tumors, suggests that a tumor suppressor gene located at this chromosomal region is involved in the tumorigenesis of GIST. However, the absence of NF2 gene mutations and the presence of merlin in the tumor tissue are evidence that another, still to be identified gene is responsible for the development of GIST.

In conclusion, even though studies on larger and homogeneous series are certainly necessary, this research can be considered very preliminary to study NF2 expression in GIST.

\section{References}

1. Miettinen M, Lasota J: Gastrointestinal stromal tumors (GISTs): definition, occurrence, pathology, differential diagnosis and molecular genetics. Pol J Pathol, 54: 3-24, 2003.

2. Hirota S, Isozaki K, Moriyama Y, Hashimoto K, Nishida T, Ishiguro S, Kawano K, Hanada M, Kurata A, Takeda M, Muhammad Tunio G, Matsuzawa Y, Kanakura Y, Shinomura Y, Kitamura Y: Gain-of-function mutations of c-kit in human gastrointestinal stromal tumors. Science, 279: 577580, 1998.

3. Heinrich MC, Corless CL, Duensing A, McGreevey L, Chen CJ, Joseph N, Singer S, Griffith DJ, Haley A, Town A, Demetri GD, Fletcher CD, Fletcher JA: PDGFRA activating mutations in gastrointestinal stromal tumors. Science, 299: 708-710, 2003.

4. Nishida T, Hirota S, Taniguchi M, Hashimoto K, Isozaki K, Nakamura H, Kanakura Y, Tanaka T, Takabayashi A, Matsuda H, Kitamura Y: Familial gastrointestinal stromal tumours with germline mutation of the KIT gene. Nat Genet, 19: 323-324, 1998.

5. Chompret A, Kannengiesser C, Barrois M, Terrier P, Dahan P, Tursz T, Lenoir GM, Bressac-De Paillerets B: PDGFRA germline mutation in a family with multiple cases of gastrointestinal stromal tumor. Gastroenterology, 126: 318321, 2004.

6. Sommer G, Agosti V, Ehlers I, Rossi F, Corbacioglu S, Farkas J, Moore M, Manova K, Antonescu CR, Besmer P: Gastroin- 
testinal stromal tumors in a mouse model by targeted mutation of the KIT receptor tyrosine kinase. Proc Natl Acad Sci USA, 100: 6706-6711, 2003.

7. Dal Cin P, Boghosian J, Sandberg AA: Cytogenetic findings in leiomyosarcoma of the small bowel. Cancer Genet Cytogenet, 30: 285-288, 1988.

8. Bardi G, Johansson B, Pandis N, Heim S, Mandahl N, Bak-Jensen E, Frederiksen H, Andren-Sandberg A, Mitelman F: Recurrent chromosome aberrations in abdominal smooth muscle tumors. Cancer Genet Cytogenet, 62: 4346, 1992.

9. el-Rifai W, Sarlomo-Rikala M, Miettinen M, Knuutila S, Andersson LC: DNA copy number losses in chromosome 14: An early change in gastrointestinal stromal tumors. Cancer Res, 56: 3230-3233, 1996.

10. Breiner JA, Meis-Kindblom J, Kindblom LG, McComb E, Liu J, Nelson M, Bridge JA: Loss of $14 q$ and $22 q$ in gastrointestinal stromal tumors (pacemaker cell tumors). Cancer Genet Cytogenet, 120: 111-116, 2000.

11. Fukasawa T, Chong JM, Sakurai S, Koshiishi N, Ikeno R, Tanaka A, Matsumoto Y, Hayashi Y, Koike M, Fukayama M: Allelic loss of 14q and 22q, NF2 mutation, and genetic instability occur independently of c-kit mutation in gastrointestinal stromal tumor. Jpn J Cancer Res, 91: 1241-1249, 2000.

12. Kim NG, Kim JJ, Ahn JY, Seong CM, Noh SH, Kim CB, Min JS, Kim H: Putative chromosomal deletions on 9p, 9q and $22 \mathrm{q}$ occur preferentially in malignant gastrointestinal stromal tumors. Int J Cancer, 85: 633-638, 2000.

13. Debiec-Rychter M, Lasota J, Sarlomo-Rikala M, Kordek R, Miettinen M: Chromosomal aberrations in malignant gastrointestinal stromal tumors: correlation with c-KIT gene mutation. Cancer Genet Cytogenet, 128: 24-30, 2001.

14. Gunawan B, Bergmann F, Hoer J, Langer C, Schumpelick V, Becker H, Fuzesi L: Biological and clinical significance of cytogenetic abnormalities in low-risk and high-risk gastrointestinal stromal tumors. Human Pathol, 33: 316-321, 2002.

15. Pylkkanen L, Sarlomo-Rikala M, Wessman M, Hamalainen E, Sainio M, Husgafvel-Pursiainen K, Carpen O: Chromosome $22 \mathrm{q}$ alterations and expression of the NF2 gene product, merlin, in gastrointestinal stromal tumors. Human Pathol, 34: 872-879, 2003.

16. Debiec-Rychter M, Pauwels P, Lasota J, Franke S, De Vos R, De Wever I, Hagemeijer A, Sciot R: Complex genetic alterations in gastrointestinal stromal tumors with autonomic nerve differentiation (GANTs). Modern Pathol, 15: 692-698, 2002.

17. Miettinen M, El-Rifai W, Sobin L, Lasota J: Evaluation of malignancy and prognosis of gastrointestinal stromal tumors: a review. Hum Pathol, 33: 478-483, 2002.

18. Miettinen M, Kopczynski J, Makhlouf HR, Sarlomo-Rikala M, Gyorffy H, Burke A, Sobin LH, Lasota J: Gastrointestinal stromal tumors, intramural leiomyomas, and leiomyosarcomas in duodenum. Am J Surg Pathol, 27: 625-641, 2003.

19. Lasota J, Jasinski M, Sarlomo-Rikala M, Miettinen M: C-kit mutations occur preferentially in malignant vs. benign gastrointestinal stromal tumors and do not occur in leiomyomas and leiomyosarcomas. Am J Pathol, 154: 5360, 1999.

20. Canzian F, Salovaara R, Hemminki A, Kristo P, Chadwick RB, Aaltonen LA, de la Chapelle A: Semiautomated assessment of loss of heterozygosity and replication error in tumors. Cancer Res, 56: 3331-3337, 1996.

21. Livak KJ, Schmittgen TD: Analysis of relative gene expression data using real-time quantitative PCR and the 2 (-Delta Delta C(T)). Methods, 25: 402-408, 2001.

22. Miettinen M, Lasota J: Gastrointestinal stromal tumors definition, clinical, histological, immunohistochemical, and molecular genetic features and differential diagnosis. Virchows Arch, 438: 1-12, 2001

23. Chan JK: Mesenchymal tumors of the gastrointestinal tract: a paradise for acronyms (STUMP, GIST, GANT, and now GIPACT), implication of c-kit in genesis, and yet another of the many emerging roles of the interstitial cell of Cajal in the pathogenesis of gastrointestinal diseases? Adv Anat Pathol, 6: 19-40, 2001.

24. Hirota S, Isozaki K, Moriyama Y, Hashimoto K, Nishida T, Ishiguro S, Kawano K, Hanada M, Kurata A, Takeda M, Muhammad Tunio G, Matsuzawa Y, Kanakura Y, Shinomura Y, Kitamura Y: Gain-of-function mutations of c-kit in human gastrointestinal stromal tumors. Science, 279: 577580, 1998.

25. Nishida T, Hirota S, Taniguchi M, Hashimoto K, Isozaki $\mathrm{K}$, Nakamura H, Kanakura Y, Tanaka T, Takabayashi A, Matsuda H, Kitamura Y: Familial gastrointestinal stromal tumours with germline mutation of the KIT gene. Nat Genet, 19: 323-324, 1998.

26. Nakahara M, Isozaki K, Hirota S, Miyagawa J, Hase-Sawada N, Taniguchi M, Nishida T, Kanayama S, Kitamura Y, Shinomura Y, Matsuzawa Y: A novel gain-of-function mutation of c-kit gene in gastrointestinal stromal tumors. Gastroenterology, 115: 1090-1095, 1998.

27. Ernst SI, Hubbs AE, Przygodzki RM, Emory TS, Sobin LH, O'Leary TJ: KIT mutation portends poor prognosis in gastrointestinal stromal/smooth muscle tumors. Lab Invest, 78: 1633-1636, 1998.

28. Lasota J, Jasinski M, Sarlomo-Rikala M, Miettinen M: Mutations in exon 11 of c-Kit occur preferentially in malignant versus benign gastrointestinal stromal tumors and do not occur in leiomyomas or leiomyosarcomas. Am J Pathol, 154: 53-60, 1999.

29. Moskaluk CA, Tian, Q, Marshall CR, Rumpel CA, Franquemont DW, Frierson HF: Mutations of c-kit JM domain are found in a minority of human gastrointestinal stromal tumors. Oncogene, 18: 1897-1902, 1999.

30. Breiner JA, Meis-Kindblom J, Kindblom LG, McComb E, Liu J, Nelson M, Bridge JA: Loss of $14 q$ and $22 q$ in gastrointestinal stromal tumors (pacemaker cell tumors). Cancer Genet Cytogenet, 120: 111-116, 2000.

31. El-Rifai W, Sarlomo-Rikala M, Andersson LC, Knuutila S, Miettinen M: DNA sequence copy number changes in gastrointestinal stromal tumors: tumor progression and prognostic significance. Cancer Res, 60: 3899-3903, 2000.

32. El-Rifai W, Sarlomo-Rikala M, Andersson LC, Miettinen M, Knuutila S: High-resolution deletion mapping of chromosome 14 in stromal tumors of the gastrointestinal tract suggests two distinct tumor suppressor loci. Genes Chromosomes Cancer, 27: 387-391, 2000.

33. Fukasawa T, Chong JM, Sakurai S, Koshiishi N, Ikeno R, Tanaka A, Matsumoto Y, Hayashi Y, Koike M, Fukayama M: Allelic loss of 14q and 22q, NF2 mutation, and genetic instability occur independently of c-kit mutation in gastrointestinal stromal tumor. Jpn J Cancer Res, 91: 1241-1249, 2000.

34. Kim NG, Kim JJ, Ahn JY, Seong CM, Noh SH, Kim CB, Min JS, Kim H: Putative chromosomal deletions on 9P, 9Q and 22Q occur preferentially in malignant gastrointestinal stromal tumors. Int J Cancer, 85: 633-638, 2000.

35. Debiec-Rychter M, Lasota J, Sarlomo-Rikala M, Kordek R, Miettinen M: Chromosomal aberrations in malignant gastrointestinal stromal tumors: correlation with c-KIT gene mutation. Cancer Genet Cytogenet, 128: 24-30, 2000.

36. Taniguchi M, Nishida T, Hirota S, Isozaki K, Ito T, Nomura T, Matsuda H, Kitamura Y: Effect of c-kit mutation on prognosis of gastrointestinal stromal tumors. Cancer Res, 59: 4297-4300, 1999

37. Sozzi G, Carney D: Molecular biology of lung cancer. Curr Opin Pulm Med, 4: 207-212, 1998. 
38. Mao L, Lee JS, Kurie JM, Fan YH, Lippman SM, Lee JJ, Ro JY, Broxson A, Yu R, Morice RC, Kemp BL, Khuri FR, Walsh GL, Hittelman WN, and Hong WK: Clonal genetic alterations in the lungs of current and former smokers. J Natl Cancer Inst, 89: 857-862, 1997.

39. Marchetti A, Pellegrini S, Bertacca G, Buttitta F, Gaeta P, Carnicelli V, Nardini V, Griseri P, Chella A, Angeletti CA, Bevilacqua G: FHIT and p53 gene abnormalities in bronchioloalveolar carcinomas. Correlations with clinicopathological data and K-ras mutations. J Pathol, 184: 240-246, 1998.

40. Miozzo M, Sozzi G, Musso K, Pilotti S, Incarbone M, Pastorino U, Pierotti MA: Microsatellite alterations in bronchial and sputum specimens of lung cancer patients. Cancer Res, 56: 2285-2288, 1996.

41. Anker P, Mulcahy H, Chen XQ, Stroun M: Detection of circulating tumour DNA in the blood (plasma/serum) of cancer patients. Cancer Metastasis Rev, 18: 65-73, 1999.
42. Chen XQ, Stroun M, Magnenat JL, Nicod LP, Kurt AM, Lyautey J, Lederrey C, Anker P: Microsatellite alterations in plasma DNA of small cell lung cancer patients. Nat Med, 2: 1033-1035, 1996.

43. Cuda G, Gallelli A, Nisticò A, Tassone P, Barbieri V, Tagliaferri PS, Costanzo FS, Tranfa CM, Venuta S: Detection of microsatellite instability and loss of heterozygosity in serum DNA of small and non-small cell lung cancer patients: a tool for early diagnosis? Lung Cancer, 30: 211-214, 2000.

44. Handel-Fernandez ME, Vincek V: Early cancer detection by microsatellite marker analysis. Med Hypotheses, 53: 114$117,1999$.

45. Sanchez-Cespedes M, Monzo M, Rosell R, Pifarre A, Calvo R, Lopez-Cabrerizo MP, Astudillo J: Detection of chromosome $3 p$ alterations in serum DNA of non-small-cell lung cancer patients. Ann Oncol, 9: 113-116, 1998. 